\title{
Relationships between fertilization of the Southeastern Pacific sea urchin Arbacia spatuligera and environmental variables in polluted coastal waters
}

\author{
Any Riveros ${ }^{1, *}$, Miguel Zuñiga ${ }^{2}$, Alberto Larrain ${ }^{1}$, José Becerra $^{3}$ \\ ${ }^{1}$ Laboratorio de Bioensayos, ${ }^{2}$ Departamento de Oceanografía, ${ }^{3}$ Laboratorio de Química de Productos Naturales, \\ Universidad de Concepción, Casilla 2407, Concepción, Chile
}

\begin{abstract}
Fertilization bioassays with the sea urchin Arbacia spatuligera were used to assess the water quality of 9 marine coastal sectors in the Biobio Region (Southern Chile) and to investigate the relationship between fertilization and environmental variables (1n situ $\mathrm{pH}$, turbidity, dissolved oxygen and salinity), heavy metals (copper, cadmium and mercury) and organic compounds (oil and grease, lindane, aldrin, dieldnn, DDE, DDT and phenols). The fertilization (mean \pm standard deviation) of $A$. spatuligera eggs in sectors with high organic discharges from fishmeal industries such as Rocuant $(14.1 \pm 6.0 \%)$ and San Vicente $(22.5 \pm 10.0 \%)$ was significantly lower $(\mathrm{p}<0.05)$ than in the other sectors (Chivilingo, Coronel, Lenga, Talcahuano, Penco, Tomé, Dichato) $(70.5 \pm 13.0 \%)$. Percent saturation of oxygen $(\mathrm{r}=0.839), \mathrm{pH}(\mathrm{r}=0.830)$, turbidity $(\mathrm{r}=-0.683)$ and oil and grease $(\mathrm{r}=-0.888)$ showed significant correlations ( $\mathrm{p}<0.001$ ) with fertilization. Principal Component Analysis (PCA) using standardized variables grouped fertilization with dissolved oxygen and $\mathrm{pH}$ (total variance of 2 first components explained $73.0 \%$ ) and Linear Multiple Regression Analysis produced the following model: Fertilization $=30.001+0.785$ (Percent saturation of oxygen) -0.059 (Oil and grease) $\left(r^{2}=0.837 ; p<0.001\right.$ ). Rocuant and San Vicente stations were grouped and separated from the rest by inverse PCA and then discriminated by Discriminant Analysis (Hotelling-Lawley Trace, $p<0.001$ ). It was concluded in laboratory bioassays that waters of coastal sectors from Rocuant and San Vicente, with the highest levels of oil and grease and lowest oxygen concentrations, had a significant effect on the fertilization of $A$. spatuligera eggs
\end{abstract}

KEY WORDS: Environmental assessment Bioassays - Sea urchin fertilization Organic pollution

\section{INTRODUCTION}

Organic pollution (i.e. eutrophication) of marine coastal waters is becoming a widespread problem throughout the world (Rosenberg 1985, Crema et al. 1991). Commonly, this phenomenon leads to high levels of organic matter in sediments, with subsequent occurrences of hypoxia or anoxia both in shallow and in bottom waters (Cederwall \& Elmgren 1990). It has been found that these altered environmental conditions may cause adverse biological effects, such as the

\footnotetext{
•E-mail: ariveros@buho.dpi.udec
}

mass mortality of benthic organisms (Elmgren 1989, Baden et al. 1990, Rosenberg 1990, Sandberg 1994).

Several sectors within a large coastal area of the Biobío Region $\left(36^{\circ} 40^{\prime} \mathrm{S}, 73^{\circ} 10^{\prime} \mathrm{W}\right)$ of southern Chile are characterized by low oxygen concentrations and large amounts of organic matter in their sediments (Ahumada \& Rudolph 1989). This region, including the Gulf of Arauco and Bays of Coliumo, San Vicente and Concepción (Fig 1), consists of semi-enclosed shallow areas with depths of about $20 \mathrm{~m}$ and very low water exchange with adjacent seawater (Ahumada et al. 1989a). Discharges from industries, coupled with active urban development, produce point and non- 


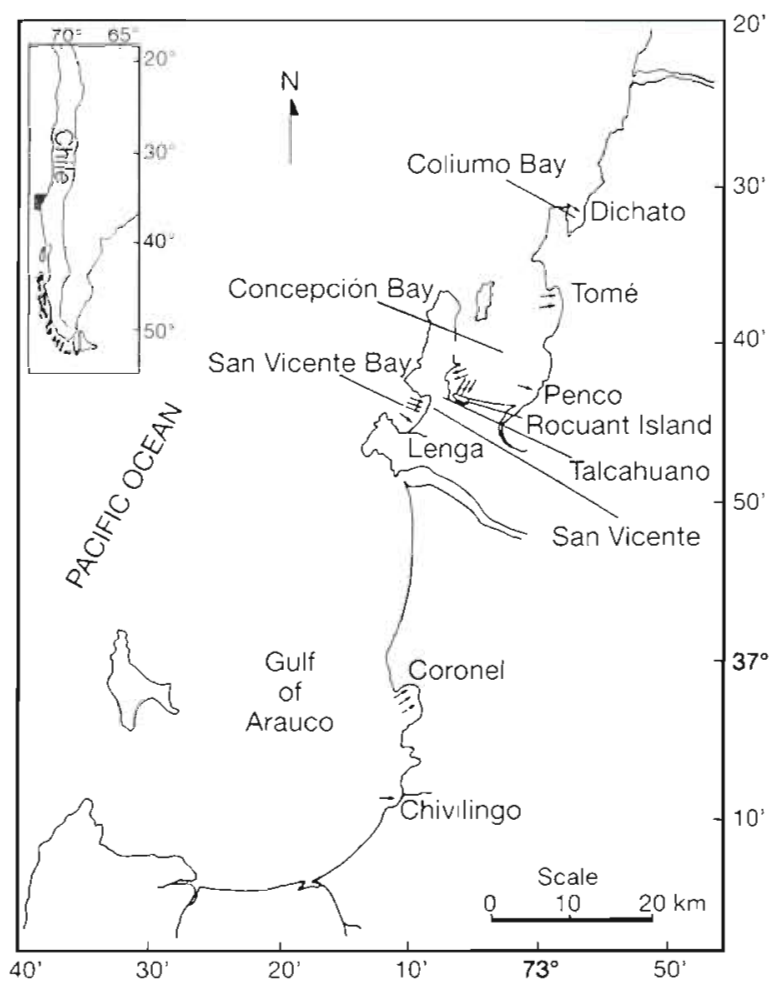

Fig. 1. Study area and sampling stations in the Biobio Region, Chile

point sources of marine pollution in the region (Chuecas 1989). In particular, Concepción and San Vicente Bays have been identified as the most polluted coastal zones in Chile as a consequence of port activities and raw sewage discharges of domestic and industrial origin.

Rudolph et al. (1984) have shown that organic pollutants from domestic sewage from the city of Talcahuano and the effluent discharges from fishmeal factories on Rocuant Island produce strong coastal pollution in Concepción Bay. Likewise, San Vicente Bay receives untreated domestic sewage and industrial discharges from fishmeal and steel mills, the liquid discharges of industrial fishing ships and untreated effluents from several chemical industries in Lenga. Various authors have reported that the severe pollution of this bay (Gallardo 1984. Ahumada et al. 1989a, Chuecas 1989, Encina 1993) causes important ecological effects, mainly benthic ecosystem alterations resulting from anoxic conditions.

Potential sources of pollution in the Gulf of Arauco include organic compounds from paper mill effluents, agricultural runoff of organochlorine pesticides through the Biobio river and release of sewage from fishmeal factories in Coronel. This port has been severely affected by high contents of organic matter in its sediments (Ahumada \& Rudolph 1989).
In spite of the intensive activities in the coastal areas within the Biobio Region, there are no organized environmental monitoring efforts and few studies have been conducted to determine the causes and effects of the pollution within this coastal zone (Chuecas 1989).

Methods to assess effects of conditions related to organic pollution on marine organisms have not yet been fully explored and little is known about the relationships between indicative parameters of organic pollution (e.g. dissolved oxygen, $\mathrm{pH}$, hydrogen sulphide and organic matter), and their biological effects. Rapid and accurate laboratory toxicity tests may be used to assess biological effects of single or combined factors related to organic pollution, monitor water quality, and to predict the potential harmful effects of contaminated environments (Richardson \& Martin 1994).

Several authors have reported the effects of single variables associated with organic pollution (e.g. hypoxia, organic enrichment) on the benthic environment (Rosenberg et al. 1991, Baden et al. 1994, Sandberg 1994, Van den Thillart et al. 1994), but studies integrating effects of multiple variables are desirable. Correlations between toxicity test results and multiple variables have only been established for sediments. Swartz et al. (1984) have shown that more than one variable from organically enriched sediments affects the survival of the amphipod Rhepoxynius abronius. Likewise, Meador et al. (1990) have shown that several sediment contaminants are related to embryo abnormalities in the sand dollar Dendraster excentricus.

The main goal of this study was to detect spatial differences in water quality from polluted and non-polluted coastal areas within the Biobío Region (ca $120 \mathrm{~km}$ of coastline) using a standardized short-term sperm toxicity test (i.e. fertilization bioassay) with the sea urchin Arbacia spatuligera. We also wished to determine the relationships between fertilization success of sea urchins and environmental factors (dissolved oxygen, salinity, $\mathrm{pH}$, turbidity), heavy metals (copper, cadmium and mercury) and organic compounds (oil and grease, lindane, aldrin, dieldrin, DDT $[1,1-$ dichloro-2,2-bis(chlorophenyl)ethylene], DDE [1,1,1trichloro-2, 2-bis(p-chlorophenyl)ethane] and phenols).

\section{MATERIALS AND METHODS}

Sampling. Four seawater samples of $200 \mathrm{ml}$ were collected by hand in the low intertidal zone at 17 coastal stations within the Biobio Region (Fig. 1). The samples were transported to the laboratory and used for bioassays within $24 \mathrm{~h}$. At each station, temperature $\left({ }^{\circ} \mathrm{C}\right)$, salinity $(\%), \mathrm{pH}$, turbidity (nephelometric units, NTU) and oxygen concentration ( $\mathrm{mg} \mathrm{l}^{-1}$ ) were measured in situ with a Horiba Water Quality Analyzer. 
Dissolved oxygen was transformed to percent saturation of oxygen according to Weiss (1970).

Water samples for copper and cadmium analyses were placed in $1 \mathrm{l}$ capped plastic bottles and stored at $4^{\circ} \mathrm{C}$. Samples for mercury analysis were placed in 0.51 capped glass bottles, acidified with concentrated nitric acid and then stored at $4^{\circ} \mathrm{C}$. Samples for organochlorine pesticides (lindane, aldrin, dieldrin, DDE, DDT), phenols, and oil and grease were taken in 2.51 brown glass bottles and stored at $4^{\circ} \mathrm{C}$ prior to analysis.

Heavy metal analyses. Methods for heavy metal analyses are described in Capelli et al. (1983). To determine copper and cadmium concentrations, seawater samples were filtered with $0.45 \mu \mathrm{m}$ Millipore filters. A $300 \mathrm{ml}$ volume of the filtrated sample was extracted by mechanical shaking over the course of $3 \mathrm{~d}$ with $0.1500 \mathrm{~g}$ of Chelex-100 resin. The water was drained and the resin dried at $35^{\circ} \mathrm{C}$. The ions were then liberated from the resin by adding $2 \mathrm{ml}$ of $1 \mathrm{~N}$ $\mathrm{HNO}_{3}$. After $1 \mathrm{~h} 8.0 \mathrm{ml}$ of distilled water was added, the solution homogenized and the resin discarded. Finally, the samples were analyzed on a Perkin Elmer Atomic Absorption Spectrophotometer (AAS) with graphite furnace. Mercury analyses were taken directly by AAS coupled to a dragging cold vapor system with stannous chloride (MHS-20).

Organic compound analyses. Methods for organic compound analyses are described in UNEP/IAEA (1982) and UNEP/IOC/IAEA (1986). The samples for organochlorine pesticides, phenols and oil and grease analyses were acidified to a $\mathrm{pH}$ of 4.0 with concentrated $\mathrm{H}_{2} \mathrm{SO}_{4}$ and then extracted 3 times with $10 \mathrm{ml}$ of $\mathrm{n}$ hexane (Merck p.a.). The extracts were mixed and dried with anhydrous $\mathrm{Na}_{2} \mathrm{SO}_{4}$ and evaporated to $5 \mathrm{ml}$ in a rotary evaporator. Excess hydrogen sulphide was eliminated with copper and excess grease with concentrated $\mathrm{H}_{2} \mathrm{SO}_{4}$. Finally, phenol concentrations were estimated with a Shimadzu UV-190 spectrophotometer at $273 \mathrm{~nm}$. Pesticides were analyzed on a Varian $2700 \mathrm{gas}$ chromatograph with electron capture detection $\left({ }^{63} \mathrm{Ni}\right)$ with $\mathrm{N}_{2}$ as the carrier gas. Quantification of pesticides was accomplished by comparing peak heights for the sample with those produced by reference standards. For the analysis of oil and grease an aliquot of the extracted sample was dried to a constant weight. Two ml of n-hexane and $1 \mathrm{ml}$ of concentrated $\mathrm{H}_{2} \mathrm{SO}_{4}$ were then added to eliminate greases. The acid phase was discarded and the organic phase was dried once again to a constant weight. The difference between the 2 weights corresponded to oil and grease in the sample.

Bioassay procedures. The methods for sperm toxicity tests were described by Weber et al. (1989) and modified by Zúñiga et al. (1995). Arbacia spatuligera adults were collected on November 1993 by SCUBA divers in Coliumo Bay $\left(36^{\circ} 32^{\prime} \mathrm{S}, 72^{\circ} 56^{\prime} \mathrm{W}\right.$ ) and trans- ported to the Marine Biology Station of Dichato, where they were acclimated in aerated flowing seawater for 1 wk. Seawater samples, collected on November 1993 , were tested undiluted (i.e. as ambient seawater) with 4 replicates per station in a randomized experimental design. In addition, a reference toxicant test (serial dilution of $\mathrm{CuSO}_{4}$ ranging from 100 to $3.125 \mathrm{\mu g} \mathrm{l}^{-1}$ of $\mathrm{Cu}^{2+}$ ) was conducted in conjunction with each series of experiments to document the performance of the bioassays. The seawater used for test controls and reference toxicant dilutions was obtained near the sea urchin collection site at Dichato. Gametes were obtained by injecting $1 \mathrm{ml}$ of $0.5 \mathrm{M} \mathrm{KCl}$ into the perivisceral fluid of 10 individuals. Undiluted sperm from 5 males was pooled and kept on ice. The eggs of 5 females were collected with a pipette, pooled in $250 \mathrm{ml}$ of seawater and held at room temperature before use in the experiments. The exposure vessels were test tubes containing $5 \mathrm{ml}$ of the seawater or referent toxicant sample. The newly collected sperm was diluted to $5 \times 10^{7}$ cells $\mathrm{ml}^{-1}$ with control seawater. A $0.1 \mathrm{ml}$ volume of this diluted sperm suspension was added to the seawater in each test tube and exposed for $1 \mathrm{~h}$. Approximately 2000 eggs were added to the test tube, following the sperm cell exposure period, and held for an additional 15 min to allow fertilization to occur. Finally, fertilization was stopped by the addition of $1 \mathrm{ml}$ of a concentrated formaldehyde solution. Temperature during conduction of bioassays was ambient $\left(16.5^{\circ} \mathrm{C}\right)$. The percentage of fertilized eggs was determinated in each replicate by microscopic examination of 100 eggs for the presence or absence of a fertilization membrane.

An additional seawater sampling was made to validate the assumption that variations in physicochemical parameters between in situ and laboratory experimental conditions do not affect the results. Samples, handled in the same manner as test samples, were used to measure the physico-chemical parameters before and after experiments. Variations (mean \pm standard deviation) between in situ and experimental measures were $10.0 \pm 6.4 \%$ for percent saturation of oxygen, $0.09 \pm$ 0.09 for $\mathrm{pH}, 0.6 \pm 0.4 \%$ for salinity, $0.8 \pm 0.6^{\circ} \mathrm{C}$ for temperature and $12 \pm 11$ NTU for turbidity.

Data analysis. Toxstat (Gulley et al. 1988) and Systat (Wilkinson 1990) programs were used for statistical analyses. Parametric analyses were validated by testing assumptions of normality and homogeneity of variances of the error terms using the arcsine (square root) transformation of fertilization data. Analysis of variance was followed by Dunnett's test in order to detect the differences between the control and treatments. The Spearman-Karber program (Hamilton et al. 1977) was used to calculate the $50 \%$ effective concentration $\left(E_{50}\right)$ for the referent toxicant test. Relationships 


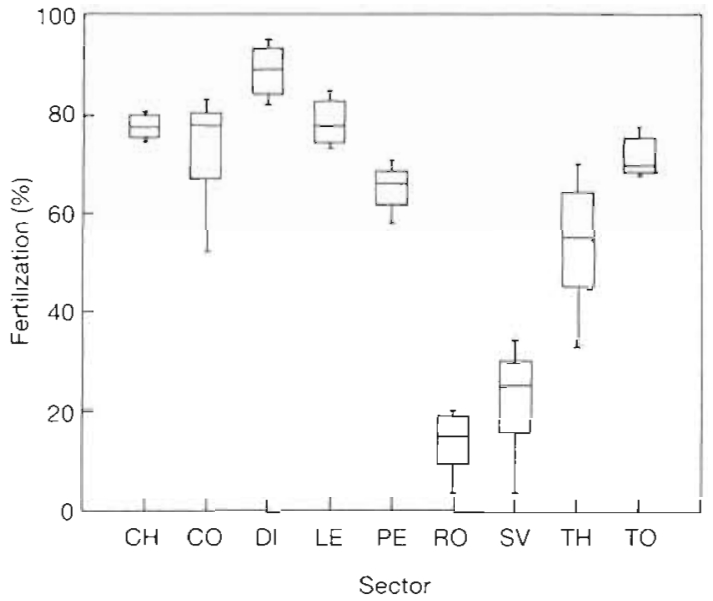

Fig. 2. Arbacia spatuligera. Box plots of fertilization in seawater samples for different coastal sectors in the Biobio Region. CH: Chivilingo; CO: Coronel; DI: Dichato; LE: Lenga; PE: Penco; RO: Rocuant; SV: San Vicente; TH: Talcahuano; TO: Tomé

between environmental variables and laboratory fertilization bioassays were validated by simple regression analyses. Principal component analysis (PCA) was used with standardized variables to detect grouping between environmental variables inorganic and organic contaminants and fertilization bioassays Inverse PCA and discriminant analysis (DA) were used to detect groups of stations with different fertilization success. Stepwise Linear Multiple Regression Analysis was used to find the relationship between fertilization and environmental variables and organic compounds.

Table 1 Mean ( \pm standard deviation) of in situ physico-chemical parameters from coastal sectors considered in the toxicity assessment in the Blobio Region - Significant differences from Dichato seawater samples (Dunnett's test; $p<0.05$ )

\begin{tabular}{|lccccc|}
\hline Sector & $\begin{array}{c}\text { Temperature } \\
\left({ }^{\circ} \mathrm{C}\right)\end{array}$ & $\begin{array}{c}\text { Salinity } \\
(\%)\end{array}$ & $\mathrm{pH}$ & $\begin{array}{c}\text { Turbidity } \\
(\mathrm{NTU})\end{array}$ & $\begin{array}{c}\text { Dissolved oxygen } \\
\text { (saturation \%) }\end{array}$ \\
\hline Dichato & 13.9 & 35.2 & 8.03 & 2 & 64.6 \\
Tomé & 16.9 & 32.6 & 7.80 & 33 & 60.8 \\
& $(0.07)$ & $(0.07)$ & $(0.05)$ & $(26)$ & $(1.2)$ \\
Penco & 1.6 .2 & 35.5 & 7.60 & $125^{\circ}$ & 41.6 \\
Rocuant & 17.0 & 35.5 & $7.16^{\circ}$ & $156^{\circ}$ & $6.3^{\circ}$ \\
& $(0.37)$ & $(0.53)$ & $(0.04)$ & $(80)$ & $(6.8)$ \\
Talcahuano & 14.8 & 34.7 & 7.30 & 37 & $19.5^{\circ}$ \\
& $(0.21)$ & $(1.70)$ & $(0.27)$ & $(4)$ & $(12.8)$ \\
San Vicente & 14.4 & 31.6 & 7.22 & $94^{\circ}$ & $14.9^{\circ}$ \\
Lenga & $(1.02)$ & $(0.64)$ & $(0.07)$ & $(30)$ & $(10.8)$ \\
Coronel & 13.3 & 32.3 & 7.62 & 19 & 57.5 \\
Chivilingo & 13.9 & 30.9 & 7.50 & $81^{\circ}$ & 48.7 \\
& $(0.26)$ & $(0.61)$ & $(0.04)$ & $(4)$ & $(11.1)$ \\
\hline
\end{tabular}

\section{RESULTS}

\section{Fertilization tests}

Control samples showed the highest fertilization success $(88.8 \pm 5.8 \%)$, indicating that sea urchin gametes were in good physiological conditions for bioassays. The $\mathrm{EC}_{50}$ obtained with the copper standard was $8.21 \mu \mathrm{g}^{-1}$ with $95 \%$ confidence intervals between 6.91 and $9.74 \mu \mathrm{g} \mathrm{I}^{-1}$

Mean fertilizations in sperm toxicity tests for seawater samples from the different sectors are presented in Fig. 2. Stations at Rocuant $(14.1 \pm 6.0 \%)$ and San Vicente $(22.5 \pm 10.0 \%)$, with the lowest fertilizations, were significantly different from stations with intermediate and high fertilizations, represented by Dichato, Tomé, Penco, Talcahuano, Lenga, Coronel and Chivilingo $(70.5 \pm 13.0 \%)$ (Dunnett's test. $\mathrm{p}<0.05$ ).

\section{Fertilization vs environmental variables}

Mean values ( \pm standard deviation) of environmental variables by sector are shown in Table 1. Mean salinity values showed little variability between sectors $(33.3 \pm 2.0 \%)$, well within the normal range for survival and reproduction of the sea urchins (Stickle \& Diehl 1987). Temperature also shows low variability between sectors $\left(15.0 \pm 1.6^{\circ} \mathrm{C}\right)$. Fertilization did not show any relationship with salinity.

Mean oxygen concentrations from Rocuant $(0.49 \pm$ $0.62 \mathrm{mg} \mathrm{l}^{-1} ; 6.3 \pm 6.8 \%$ saturation), San Vicente (1.24 \pm $1.06 \mathrm{mg} \mathrm{l}^{-1} ; 14.9 \pm 10.8 \%$ saturation) and Talcahuano $\left\{1.59 \pm 1.39 \mathrm{mg} \mathrm{l}^{-1} ; 19.5 \pm 12.8 \%\right.$ saturation) were significantly lower than in the rest of sectors combined $4.56 \pm$ $0.88 \mathrm{mg} \mathrm{l}^{-1} ; 54.9 \pm 9.9 \%$ saturation; Dunnett's test, $\mathrm{p}<0.05$; Table 1 ). The poor environmental conditions of Rocuant, San Vicente and Talcahuano were correlated with low oxygen concentrations. Fertilization was positively correlated with in situ oxygen concentration $(r=0.839 ; p<0.001$; Fig. 3a). Most sectors with low oxygen concentrations $\left(<2.5 \mathrm{mg} \mathrm{l}^{-1} ; 30.1 \%\right.$ saturation) had fertilization success below $40 \%$, while water samples with oxygen concentrations between 3.0 and $5.8 \mathrm{mg} \mathrm{l}^{-1}$ (i.e. between 36 and $70 \%$ saturation) had fertilizations above $50 \%$ (Fig. 3a).

Mean pH from Rocuant $(7.16 \pm 0.04)$ and San Vicente $(7.22 \pm 0.07)$ were significantly lower than in the rest of 

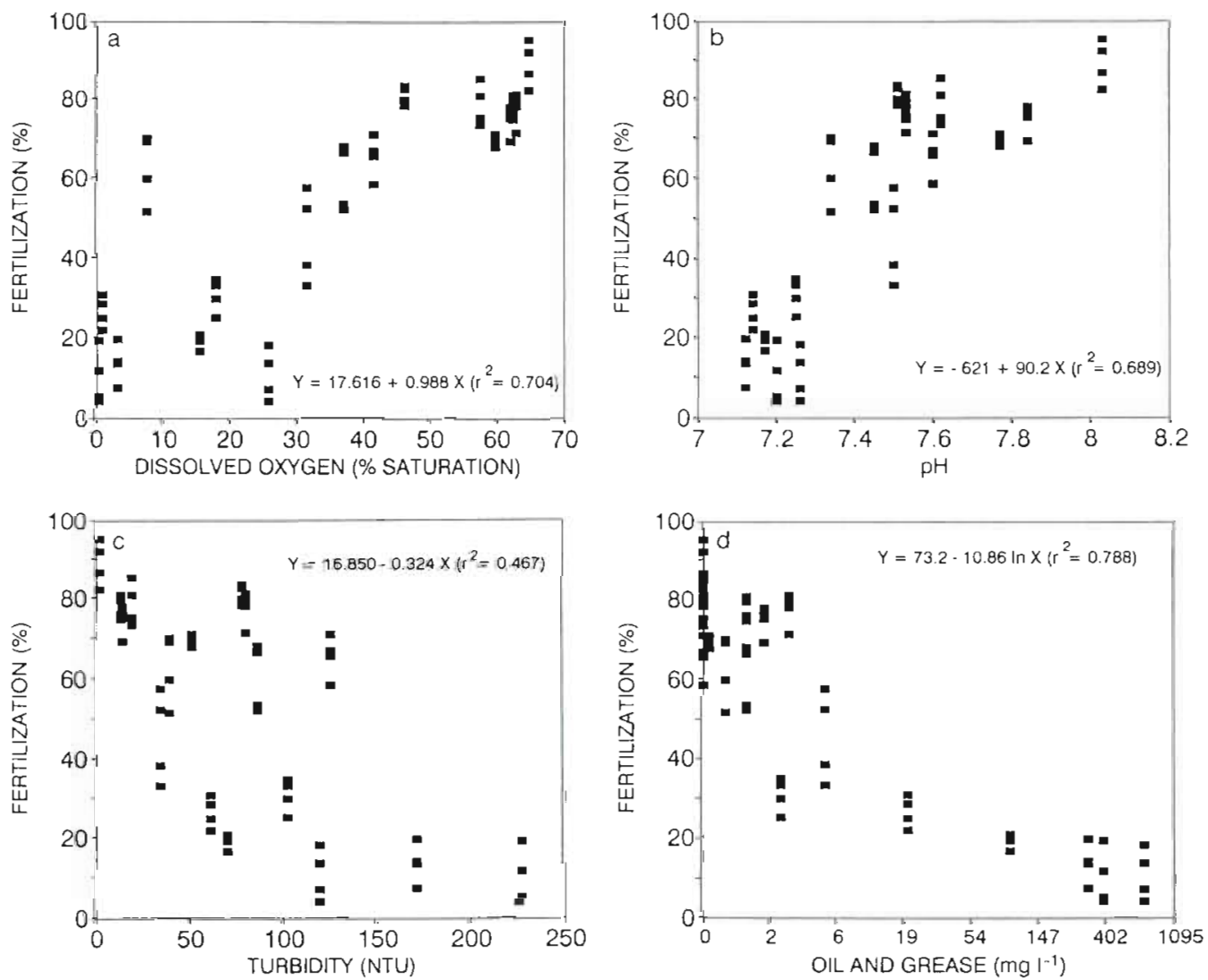

Fig. 3. Arbacia spatuligera. Fertilization success plotted against in situ (a) percent saturation of oxygen $(r=0.839, p<0.001)$, (b) $\mathrm{pH}(\mathrm{r}=0.830, \mathrm{p}<0.001)$, (c) turbidity $(\mathrm{r}=-0.683, \mathrm{p}<0.001)$ and (d) oil and greases $(\mathrm{r}=-0.888, \mathrm{p}<0.001)$

sectors $(7.59 \pm 0.24 ; \mathrm{p}<0.01 ;$ Table 1$)$. Fertilization was positively correlated with in situ pH $(r=0.830, \mathrm{p}<$ 0.001 ; Fig. 3b). Water samples with $\mathrm{pH}$ values below 7.3 showed fertilization success below $35 \%$; those with higher $\mathrm{pH}$ values showed increased fertilization success (Fig. 3b).

Mean turbidity in Racuant (156 \pm 80 NTU), Penco (125 NTU), Coronel $(81 \pm 4$ NTU) and San Vicente (94 \pm 30 NTU) were significantly higher than in the rest of sectors ( $25 \pm 17 \mathrm{NTU}$; $\mathrm{p}<0.05$; Table 1). Fertilization was negatively correlated with in situ turbidity ( $\mathrm{r}=$ $-0.683, p<0.001$; Fig. 3c). Most water samples with turbidity values above 50 NTU showed fertilization success lower than 30\%, while those with turbidity below 50 NTU had higher fertilization success (Fig. 3c).

\section{Fertilization vs heavy metals}

Heavy metal concentrations for the different sectors within the Biobio Region are shown in Table 2. In general, the 3 metals showed no significant variations between sectors. Mean seawater concentrations of copper $\left(0.61 \pm 0.47 \mathrm{\mu g} \mathrm{l}^{-1}\right)$ were similar to unpolluted seawater concentrations $\left(0.64 \mu \mathrm{g} \mathrm{l}^{-1}\right)$ and below US EPA $(1976,1982)$ water quality criteria $\left(10\right.$ to $\left.43 \mu^{-1} \mathrm{~g}^{-1}\right)$. Concentrations of cadmium $\left(0.05 \pm 0.03 \mu \mathrm{g} \mathrm{l}^{-1}\right)$ and mercury $\left(0.05 \pm 0.04 \mathrm{\mu g}^{-1}\right)$ were slightly above unpol-

Table 2. Mean seawater concentrations $\left(\mu \mathrm{g} \mathrm{l}^{-1}\right)$ of copper, cadmium and mercury in the Biobio Region

\begin{tabular}{|c|c|c|c|}
\hline Sampling sector & Copper & Cadmium & Mercury \\
\hline Dichato & 0.16 & $<0.02$ & 0.03 \\
\hline Tomé & 1.41 & 0.08 & $<0.02$ \\
\hline Penco & 0.69 & $<0.02$ & 0.03 \\
\hline Rocuant & 0.38 & 0.06 & 0.09 \\
\hline Talcahuano & 0.51 & 0.05 & 0.03 \\
\hline San Vicente & 0.60 & 0.02 & 0.04 \\
\hline Lenga & 0.51 & $<0.02$ & 0.03 \\
\hline Coronel & 0.36 & 0.03 & 0.03 \\
\hline Chivilingo & 1.09 & 0.10 & 0.03 \\
\hline Unpolluted seawaters $^{\mathrm{d}}$ & 0.64 & 0.025 & 0.012 \\
\hline Water quality criteriab & $10-43$ & $5-10$ & $0.1-1.0$ \\
\hline \multicolumn{4}{|c|}{ ¿Furness \& Rainbow (1990) } \\
\hline \multicolumn{4}{|c|}{ 'US EPA $(1976,1982)$ and Kobylinski et al. (1993) } \\
\hline
\end{tabular}


luted seawater concentrations $\left(0.025 \mu \mathrm{g} \mathrm{l}^{-1}\right.$ for $\mathrm{Cd}$ and $0.012 \mu \mathrm{g} \mathrm{l}^{-1}$ for $\mathrm{Hg}$ ) but were also below US EPA (1976, 1.982) water quality criteria ( 5 to $10 \mathrm{\mu g} \mathrm{I}^{-1}$ for $\mathrm{Cd}$ and 0.1 to $1.0 \mathrm{\mu g} \mathrm{l}^{-1}$ for $\mathrm{Hg}$ ). No significant correlations were found between fertilization success and copper, cadmium or mercury concentrations

\section{Fertilization vs organic compounds}

The concentrations of organic compounds within the Biobío Region are shown in Table 3. Seawater phenol concentrations varied between 0.01 and $0.745 \mu \mathrm{g} \mathrm{l}^{-1}$ with the highest values in San Vicente $\left(0.745{\left.\mu \mathrm{g} \mathrm{I}^{-1}\right)}^{-1}\right.$ and Rocuant $\left(0.126 \mu \mathrm{g} \mathrm{l}^{-1}\right)$, both below US EPA (1982) water quality criteria $\left(1.0 \mu \mathrm{g} \mathrm{I}^{-1}\right)$.

In some sectors organochlorine pesticide concentrations fell below detectable levels $\left(<0.001 \mu \mathrm{g} \mathrm{l}^{-1}\right)$. The highest concentrations of lindane were found in San Vicente $\left(0.060 \mu \mathrm{g} \mathrm{l}^{-1}\right)$, Rocuant $\left(0.046 \mu \mathrm{gl}^{-1}\right)$ and Talcahuano $\left(0.036 \mathrm{\mu g} \mathrm{l}^{-1}\right)$. These concentrations are above both unpolluted (Antarctic) seawaters $\left(0.126 \mathrm{ng} \mathrm{l}^{-1}\right)$ and

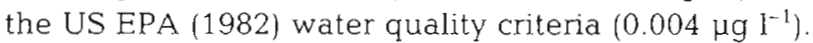
The highest concentrations of aldrin-dieldrin were detected in Rocuant $\left(0.180 \mu \mathrm{g}^{-1}\right)$, San Vicente $\left(0.148 \mu \mathrm{g}^{-1}\right)$ and Talcahuano $\left(0.148 \mu \mathrm{g} \mathrm{l}^{-1}\right)$. These concentrations are also greater than both unpolluted (Antarctic) seawaters (0.086 $\left.\mathrm{ng} \mathrm{l}^{-1}\right)$ and US EPA (1982) water quality criteria $\left(0.006 \mu \mathrm{g} \mathrm{I}^{-1}\right)$. Water concentrations of DDT-DDE in Talcahuano $\left(0.061 \mu \mathrm{g} \mathrm{l}^{-1}\right)$, San Vicente $\left(0.057 \mu \mathrm{g} \mathrm{l}^{-1}\right)$, Coronel $\left(0.030 \mathrm{\mu g}^{-1}\right)$ and Rocuant $\left(0.024 \mathrm{\mu g} \mathrm{l}^{-1}\right)$ were many times above unpolluted waters $\left(0.424 \mathrm{ng} \mathrm{l}^{-1}\right)$ and US EPA (1982) water quality criteria $\left(0.002 \mu \mathrm{g} \mathrm{l}^{-1}\right)$. However, no significant correlations were found between fertilization and phenols and organochlorine pesticides.

Table 3. Mean seawater concentrations of pesticides $\left(\mu \mathrm{g} \mathrm{l}^{-1}\right)$, phenols $\left(\mu \mathrm{g}^{-1}\right)$ and oil and grease $\left(\mathrm{mg} \mathrm{l}^{-1}\right)$ in the Biobio Region

\begin{tabular}{|c|c|c|c|c|c|}
\hline Sampling sector & Phenols & Lindane & $\begin{array}{l}\text { Aldrin + } \\
\text { dieldrin }\end{array}$ & $\begin{array}{c}\mathrm{DDT}+ \\
\mathrm{DDE}\end{array}$ & $\begin{array}{l}\text { Oil and } \\
\text { grease }\end{array}$ \\
\hline Dichato & 0.010 & 0.006 & 0.004 & 0.002 & 0.0 \\
\hline Tomé & 0.030 & 0.008 & 0.007 & 0.009 & 0.8 \\
\hline Penco & 0.030 & 0.006 & $<0.001$ & $<0.001$ & 0.0 \\
\hline Rocuant & 0.126 & 0.046 & 0.180 & 0.024 & 260.3 \\
\hline Talcahuano & 0.028 & 0.036 & 0.148 & 0.061 & 2.8 \\
\hline San Vicente & 0.74 .5 & 0.060 & 0.148 & 0.057 & 240.1 \\
\hline Lenga & 0.010 & 0.002 & 0.006 & 0.002 & 0.0 \\
\hline Coronel & 0.098 & $<0.001$ & 0.063 & 0.030 & 1.2 \\
\hline Chivilingo & 0.020 & $<0.001$ & 0.006 & $<0.001$ & 0.9 \\
\hline Unpolluted seawaters ${ }^{\mathrm{a}}$ & - & $1.26 \times 10^{-4}$ & $0.86 \times 10^{-4}$ & $4.24 \times 10^{-4}$ & - \\
\hline Water quality criteriab & 1.000 & 0.004 & 0.006 & 0.002 & 25.0 \\
\hline
\end{tabular}

Oil and grease concentrations show high variability between stations, with values in Rocuant $(260.3 \pm 148.7$ $\left.\mathrm{mg}^{-1}\right)$ and San Vicente $\left(240.1 \pm 396.7 \mathrm{mg} \mathrm{l}^{-1}\right)$ significantly higher than in the remaining sectors considered together $\left(1.1 \pm 1.6 \mathrm{mg} \mathrm{l}^{-1}\right)$ [data transformed to $\ln (x+1)$; Dunnett's test, $\mathrm{p}<0.05$; Table 31. Concentrations of oil and grease both in Rocuant and San Vicente were above US EPA (1982) water quality criteria (25.0 $\mathrm{mg}$ $\left.\mathrm{l}^{-1}\right)$. Fertilization was negatively correlated with oil and grease ( $r=-0.888, p<0.001$; Fig. 3d). Most water samples with oil and grease concentrations above $5 \mathrm{mg} \mathrm{l}^{-1}$ showed fertilizations lower than $45 \%$, while those with concentrations below $5 \mathrm{mg} \mathrm{l}^{-1}$ had higher fertilizations (Fig. 3d).

\section{Multivariate analyses}

PCA applied over environmental factors, heavy metals and organic contaminants showed that the first 2 principal components explained $73 \%$ of the total variance. Principal Component 1 was explained mainly by fertilization $(r=-0.947$ ). This analysis showed that fertilization was positively correlated with variables located to the left (dissolved oxygen and pH) and negatively correlated with variables located to the right (turbidity, aldrin, total organochlorine pesticides, phenols and oil and grease) (Fig. 4).

When a Stepwise Linear Multiple Regression Analysis was applied, considering fertilization as the dependent variable, the following model was obtained: Fertilization $=30.001+0.785$ (Percent saturation of oxygen) -0.059 (Oil and grease) $\left(\mathrm{r}^{2}=0.837 ; \mathrm{p}<0.001\right.$ ) The high multiple regression correlation coefficient indicates that fertilization is influenced more by seawater oxygen and by oil and grease concentrations than by the other variables examined. The first 2 principal components from inverse PCA explained $89 \%$ of total variance as shown in Fig. 5. Component axis 2 was well correlated with fertilization ( $\mathrm{r}=$ -0.873 ). Stations located at the top of axis 2 (Rocuant and San Vicente) share very low fertilizations. Discriminant Analysis (Fig 6) confirmed that stations at Rocuant and San Vicente were significantly different from the others (Hotelling-Lawley Trace, p < 0.001 ), locating stations with lowest fertilization success to the right of the graph (i.e. Rocuant and San Vicente). Factor 1 was well correlated with component axis $2(r=0.894)$ and fertilization $(r=-0.996)$ 


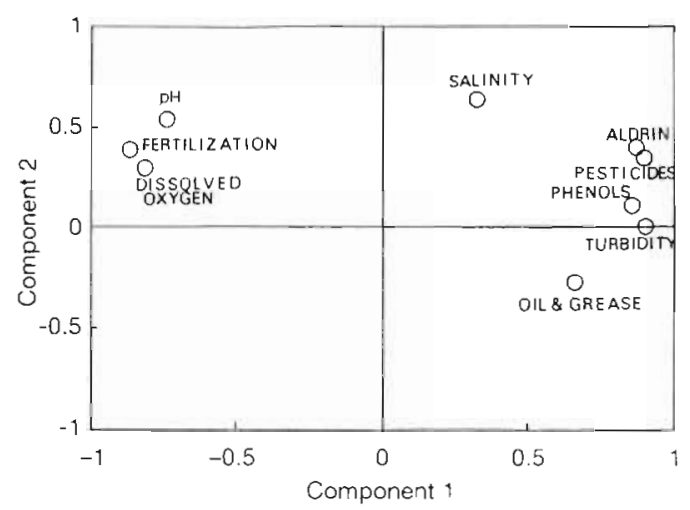

Fig. 4. Principal component analysis showing the distribution of standardized variables (Arbacia spatuligera fertilization success, in situ physico-chemical parameters and organic contaminants) along 2 principal component axes using coastal seawater stations in the Biobio Region (total variance explained by first 2 components: $\mathrm{PC} 1=58.8 \%, \mathrm{PC} 2=14.2 \%$ )

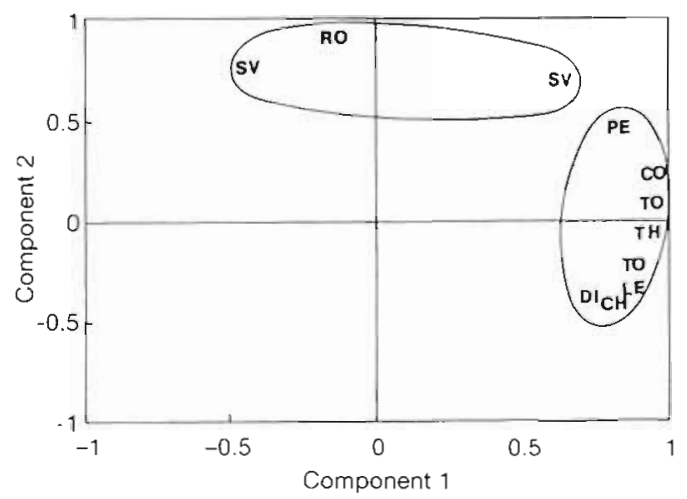

Fig. 5. Inverse principal component analysis showing the distribution of stations along the 2 principal component axes using as row data fertilization, physico-chemical parameters and organic contaminants (total variance explained by first 2 components: $\mathrm{PC} 1=60.0 \%, \mathrm{PC} 2=28.8 \%)$. $\mathrm{CH}$ : Chivilingo; CO: Coronel; DI: Dichato; LE: Lenga; PE: Penco; RO: Rocuant; SV: San Vicente; TH: Talcahuano; TO: Tomé

\section{DISCUSSION}

\section{Bioassay assessment}

In the last decade, sea urchin sperm toxicity tests (i.e. fertilization bioassays) have been used to detect differences in seawater quality and to give quantitative information about unpolluted and polluted areas (Dinnel et al. 1988, Kobayashi 1991). In an extensive water quality assessment, we tested differences in fertilization success of the sea urchin Arbacia spatuligera between several unpolluted and polluted coastal waters within the Biobío Region and focused on detection of the environmental factors and contaminants sig-

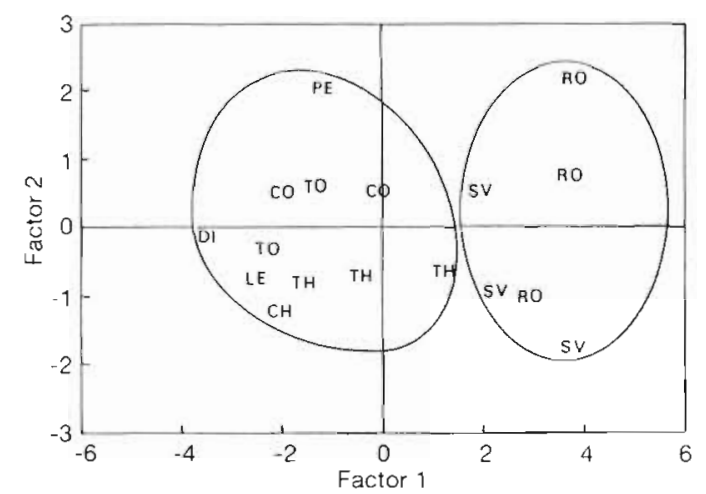

Fig. 6. Discriminant analysis of environmental variables and toxicities for coastal sectors in the Biobio Region. (Groups are significantly different, Hotelling-Lawley Trace, $p<0.001$.) $\mathrm{CH}$ : Chivilingo; CO: Coronel; DI: Dichato; LE: Lenga; PE: Penco; RO: Rocuant; SV: San Vicente; TH: Talcahuano; TO: Tomé

nificantly related to these differences. Fertilization in sea urchins includes sperm activation following contact with seawater after its release from the gonads. Many physiological events, including movement of the sperm flagellum, may be affected by poor environmental conditions or the presence of chemical pollutants during toxicity tests (Dinnel et al. 1989). For example, metabolic events during the activation of the sperm may be affected by changes in dissolved oxygen and $\mathrm{pH}$ (Giudice 1986).

In a previous report Zúniga et al. (1995) found that water samples from Rocuant Island and San Vicente significantly decreased fertilization success in Arbacia spatuligera. Our results from water quality assessment in a more extensive area within the Biobio Region confirm that the Rocuant and San Vicente sectors produced the lowest percent fertilization in the sea urchin bioassays. When fertilization was related to environmental factors, it was found that fertilization success was positively correlated with dissolved oxygen and $\mathrm{pH}$ and negatively correlated with turbidity. Therefore, the poorest seawater quality situations in coastal environments, as reflected by the lowest fertilizations in $A$. spatuligera, were associated with low oxygen levels, low $\mathrm{pH}$ and high turbidity. We found that anoxic conditions are present in sectors with the highest inputs of organic matter and that oxygen concentration is directly related to $\mathrm{pH}\left(\mathrm{r}^{2}=0.741, \mathrm{p}<\right.$ 0.001 ). One explanation for this relation is that aerobic and anaerobic metabolism of high contents of organic matter consume dissolved oxygen and produce high levels of carbon dioxide and hydrogen sulfide that finally reduce pH (Riley \& Chester 1971, Aubert 1990). 


\section{Relationships between fertilization and environmental variables}

It has been suggested that gametes and embryos are the stages in the life cycle of marine invertebrates which are most sensitive to anoxia and hypoxia (Lutz et al. 1994). Rosenberg et al. (1991) have reported that many marine benthic species are very sensitive to low oxygen concentrations, with a lower tolerance limit of $1 \mathrm{ml} \mathrm{l}^{-1}$ (ca $1.43 \mathrm{mg} \mathrm{l}^{-1}$ ). Accordingly, our results showed that in situ oxygen concentrations of 1 to $2 \mathrm{mg}$ $\mathrm{l}^{-1}$ reduced fertilization success in Arbacia spatuligera to below $50 \%$ (between 46 and $26 \%$ in the linear model).

The relationship between fertilization success and in situ $\mathrm{pH}$ indicated that seawater samples with a $\mathrm{pH}$ of 7.1 to 7.3 reduced fertilization success to below $40 \%$ (in the linear model between 38 and $17 \%$ ). These low fertilization levels might be due to the inactivation of sperm caused by low pH. Christen et al. (1983) pointed out that $\mathrm{pH}$ variations affected the motility of sperm, suggesting that low internal $\mathrm{pH}(7.0)$ prevents motility of sperm within the gonad, by inhibiting the dynein ATP-ase, which is rate-limiting for the respiration of tightly coupled mitochondria. Alkalinization of the internal pH (8.0) acts as an activator of the ATP-ase, increasing sperm respiration rate and motility.

Turbidity has been used as a parameter indicative of suspended particulates and it has been established that such particulates may adsorb and transport high levels of organic pollutants (e.g. organochlorine pesticides and polycyclic aromatic hydracarbons; Bouloubassi \& Saliot 1991). Water samples from polluted sectors within the Biobio Region showed high levels of suspended particulates (i.e. turbidity) which are associated with high concentrations of organochlorine pesticides ( $r=0.814$ ). This could contribute to the significant reduction of fertilization success in the laboratory bioassays.

Additionally, low oxygen concentrations, low $\mathrm{pH}$ and high levels of suspended solids might induce additive or synergystic negative effects on physiological processes during fertilization of Arbacia spatuligera in seawater

\section{Relationships between fertilization and inorganic and organic contaminants}

In most stations, concentrations of copper, mercury and cadmium were near those of unpolluted seawaters or below US EPA $(1976,1982)$ water quality criteria. This could explain the lack of correlation between heavy metals and fertilization success in Arbacia spatuligera. Potential sources of heavy metal within the region are scarce. The main discharges originate in steel mills in San Vicente (Gallardo 1984). Additionally, the area might be subjected to aerial deposition of cadmium and mercury from fossil fuel combustion, as shown by Taylor (1993) elsewhere. However, the low metal concentrations found in coastal seawaters in this study indicate little or no heavy metal pollution in the Biobio Region.

The correlation between fertilization success and concentration of oil and grease was highly significant. It has been suggested that oil and grease are an unidentified group of hydrophobic compounds, associated with high levels of organic contaminants such as phenols and organochlorine pesticides (US EPA 1976). We found that stations with the highest levels of oil and grease (Rocuant and San Vicente sectors) showed the lowest fertilization success. Similarly, Swartz et al. (1984) found that relative toxicities of sewage sludges for the infaunal marine amphipod Rhepoxynius abronius were correlated with multiple factors, mainly with the concentration of oil and grease.

Organochlorine pesticides (e.g. DDT, dieldrin, lindane) are considered to be major environmental contaminants because they are accumulated in fatty tissues, produce high toxicity to many invertebrate species and are persistent in aquatic ecosystems (WHO 1989, Pridmore et al. 1991). Chuecas et al. (1991) have reported that concentrations of organochlorine pesticides in coastal seawaters within the Biobio Region are above EPA (1976) water quality criteria, in spite of governmental restrictions on their import, manufacture, sale and agricultural use. Our results show that levels of organochlorine pesticides are still above these criteria. The interactions between these contaminants might have strong negative effects in processes as sensitive as fertilization in marine invertebrates. However, in our study we did not find significant correlations between fertilization and the concentrations of phenols and different organochlorine pesticides (aldrin, dieldrin, lindane, DDT). The highest concentrations of these organic contaminants were detected in Rocuant Island and San Vicente sectors.

If the station with the highest concentrations of oil and grease (located in San Vicente Bay) is excluded from the analysis, fertilization shows a better correlation with phenols $(r=-0.633, p<0.001$, Fig. 7a) and total organochlorine pesticides $(r=-0.633, p<0.001$; Fig. $7 \mathrm{~b}$ ). When a backward linear multiple regression analysis was applied to these data, we found the following model: Fertilization $=41.793-315.689$ (Phenols) -0.348 (Oil and greases) +0.572 (Saturation \% of oxygen) +480.038 (Organochlorine pesticides) $\left(r^{2}=0.919\right.$, $p<0.001$ ) The results of these analyses indicate that high levels of oil and grease are associated with high levels of organic contaminants and that both are 

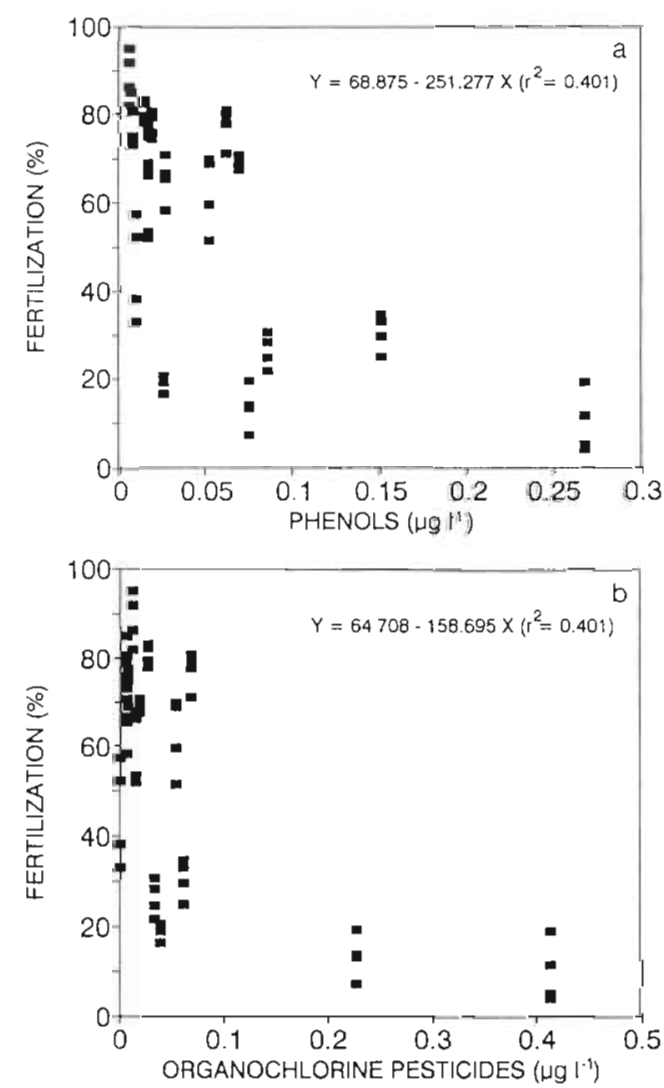

Fig. 7 Arbacia spatuligera. Fertilization success plotted against (a) phenols $(\mathrm{r}=-0.633, \mathrm{p}<0.02)$ and (b) organochlorine pesticides $(r=-0.633, p<0.02)$

related to decreased fertilization success in Arbacia spatuligera. On the basis of these data we suggest that Rocuant Island and San Vicente Port are the most polluted sectors within the Biobio Region.

\section{Bioassay assessment and organic pollution within the Biobío Region}

In many enclosed coastal marine areas, high organic sewage discharges producing extremely low oxygen concentrations in bottom waters have been identified with organic pollution processes (Rosenberg 1985. 1990). For many years, this process has been observed in semi-enclosed bays within the Biobio Region (Ahumada \& Rudolph 1989, Ahumada et al. 1989b). According to our study, the most important seawater variables related to toxicity (i.e. decreased fertilization) were dissolved oxygen (positively related) and oil and grease (negatively related), both highly related to sewage pollution in the Region (Pradenas \& Rudolph 1989). Oil and grease have been related to high loads of organic matter of untreated discharges of fishmeal factories (Rudolph et al. 1984). Low dissolved oxygen might be a consequence of high accumulation rates of this organic matter in the sediments.

Little is yet known about the potential toxic effects of chemical substances contained in the discharges of organic sewage (Swartz et al. 1984). It has been suggested that in the long term these discharges produce organic pollution, with important effects on the structure and energetic flows of benthic communities. Rosenberg (1985) and Baden et al. (1990) have associated organic pollution with mortality of benthic infauna and demersal fishes in waters of west Sweden; Crema et al. (1.991) recorded immature communities with abundance of species of early succesional stages in a highly organic polluted area within the Northern Adriatic Sea; Zmarzly et al. (1994) have reported that organic enrichment from wastewater discharges may increase relative abundances of small species and reduce temporal persistence of soft-bottom assemblages on the southern San Diego shelf.

In the Biobio Region, Oyarzún et al. (1987) have detected high density and biomass of opportunistic species associated with high organic matter enrichment in coastal sediments in Concepcion Bay. Carbajal-Villalta (1994) mentioned that the increase of organic enrichment in coastal sediments could be responsible for long-term perturbations of the structure and dynamics of benthic macrofaunal communities within San Vicente Bay.

Although direct relationships between specific pollutants in organically polluted environments and biological responses in the laboratory have not been firmly established, our results suggest that multiple interactions between physico-chemical variables and organic pollutants can have significant effects on fertilization success in sea urchins. This might also have negative effects on the reproduction of other species of invertebrates belonging to these coastal ecosystems.

\section{CONCLUSIONS}

The results of sea urchin fertilization bioassays and the relationship between fertilization and environmental variables provided confirmation of organic pollution in the bays of the Biobio Region. However, according to Swartz et al. (1984), single-species toxicity test results should not be extrapolated uncritically to field situations.

We conclude that semi-enclosed coastal marine environments in the Biobio Region, mainly Rocuant Island and San Vicente Bay, are subject to organic pollution, which is demonstrated by the presence of high levels of organic compounds (mainly oil and grease) 
and low oxygen concentrations. These extreme conditions were related to biological effects, as shown by decreased fertilization in Arbacia spatuligera.

Acknowledgements. We are grateful to George Morrison from the Environmental Research Laboratory of Rhode Island US EPA, Paul Dinnel from Dinnel Marine Research at Washington, Jared Rubin from the US Peace Corps-EL LA Center, Universidad de Concepción, Valery Petrosyan from M.V. Lomonosov University at Moscow and Rutger Rosenberg from the Marine Research Station at Kristineberg, Sweden, for valuable comments and suggestions that significantly improved the manuscript. We also thank Ruben Roa from Instituto de Fomento Pesquero for his statistical comments, the EULA Center for the heavy metal analyses and José Caamaño from the Marine Biology Station at Dichato for diving for the sea-urchin specimens. This work was partially funded through project D.I.C. 923829 to A. Larrain.

\section{LITERATURE CITED}

Ahumada R, Rudolph A (1989) Residuos líquidos de la industria pesquera: alteraciones ambientales $y$ estrategias de eliminación. Ambiente Desarrollo 5:147-161

Ahumada R, Rudolph A, Madariaga S, Carrasco F (1989a) Descripción de las condiciones oceanográficas de la Bahía San Vicente y antecedentes sobre los efectos de la contaminación. Biol Pesq 18:37-52

Ahumada R, Troncoso A, Rudolph A, Morillas J, Contreras T (1989b) Coloración roja producida por bacterias: Marisma Rocuant, Talcahuano. Bol Soc Biol Concepción 60:7-16

Aubert M (1990) Mediators of microbiological origin and eutrophication phenomena. Mar Pollut Bull 21:24-29

Baden SP, Depledge MH, Hagerman L (1994) Glycogen depletion and altered copper and manganese handling in Nephrops norvegicus following starvation and exposure to hypoxia. Mar Ecol Prog Ser 103:65-72

Baden SP, Loo LO, Pihl L, Rosenberg R (1990) Effects of eutrophication on benthic communities including fish: Swedish West Coast. Ambio 19:113-122

Becerra J, González F, Chuecas L, Pantoja S, Silva M (1992) Pesticidas organoclorados e hidrocarburos derivados del petróleo en el Paso Drake, Estrecho Bransfield e Islas Shetland del Sur. In: Gallardo VA, Ferretti O, Moyano HI (eds) Oceanografía en Antártica. ENEA-Proyecto Antártica-Italia, Concepción, p 108-115

Bouloubassi Y. Saliot A (1991) Composition and sources of dissolved and particulate PAH surface waters from the Rhone Delta (NW Mediterranean). Mar Pollut Bull 22:588-594

Capelli R, Confardi V, Fossato VU, Frache R (1983) Metodologie analitiche per lo studio della qualita dell'ambiente marino. Consiglio Nazionale delle Ricerche, Genova

Carbajal-Villalta W (1994) Efectos del enriquecimiento orgánico sobre la macroinfauna sublitoral de la Bahía San. Vicente, Chile Central. Tesıs MCs Oceanografía, Universidad de Concepción, Chile

Cederwall H, Elmgren R (1990) Biological effects of eutrophication in the Baltic Sea, particularly the coastal zone. Ambio 19:109-112

Christen R., Schackmann RW, Shapiro BM (1983) Metabolism. of sea urchin sperm. Interrelationships between intracellular $\mathrm{pH}$, ATPase activity, and mitochondrial respiration. J Biol Chem 258:5392-5399

Chuecas L (1989) Contaminación por metales pesados en el litoral de la Octava Región del Biobio, Concepción, Chile: el caso del mercurio y el cadmio. Ambiente Desarrollo 5: $1.37-145$

Chuecas LM. Glasinovic A, Camaño A (1991) Estudios de linea base sobre pesticidas organoclorados en agua, sedimentos y organismos marinos de la zona costera de la Región del Biobío, Chile. In: Escobar JJ (ed) Comisión Permanente del Pacifico Sur. Memorias del primer seminario internacional sobre investigación y vigilancia de la contaminación marina en el Pacífico Sudeste. Comisión Permanente del Pacifico Sur, Cali

Crema R, Castelli A, Prevedelli D (1991) Long term eutrophication effects on macrofaunal communities in Northern Adriatic Sea. Mar Pollut Bull 22:503-508

Dinnel PA, Link JM, Stober QJ, Letourneau MW, Roberts WE (1989) Comparative sensitivity of sea urchin sperm bioassays to metals and pesticides. Arch Environ Contam Toxicol 18:748-755

Dinnel PA, Pagano G, Oshida PS (1988) A sea urchin test system for marine environmental monitoring. In: Burke RD, Mladenov PV, Lamber P, Parsley RL (eds) Echinoderm biology. Balkema, Rotterdam, p 611-619

Elmgren R (1989) Man's impact on the ecosystem of the Baltic Sea: energy flows today and at the turn of the century. Ambio 18:326-332

Encina F (1993) Estudio de metales (Cu, Zn, Pb, Cd, y Hg) en Iridaea laminaroides, Iridaea ciliata y Gracilaria chilensis (Rhodophyta-Gigartinales) en las Bahías San Vicente, Coliumo y Quidico (Octava Región-Chile). Tesis Dr Ciencias Ambientales, Centro Eula-Universidad de Concepción, Chile

Furness RW, Rainbow PR (1990) Heavy metals in the marine environment. CRC Press, Inc, London

Gallardo VA (1984) Revisión actualizada a 1983 de la contaminación marina proveniente de fuentes terrestres en la región del Pacífico Sudeste (Colombia, Chile, Ecuador, Panamá y Perú). Rev Com Perm Pacífico Sur 14:19-173

Giudice G (1986) The sea urchin embryo. A developmental biological system. Springer-Verlag, Berlin

Gulley DD, Boelter AM, Bergman HL (1988) TOXSTAT 2.1 Fish Physiology and Toxicology Laboratory, Department of Zoology and Physiology, University of Wyoming, Laramie

Hamilton MA, Russo RC, Thurston RV (1977) Trimmed Spearman-Karber Method for estimating median lethal concentrations in toxicity bioassays. Environ Sci Technol 11. $714-719$

Kobayashi N (1991) Marine pollution bioassay by using sea urchin eggs in the Tanabe Bay, Wakayama Prefecture, Japan, 1970-1987. Mar Pollut Bull 23:709-713

Kobylinski EA, Hunter GL, Quinlan EA (1993) Implementing the new water quality standards. Fitting the puzzle together. Environ Prog 12:169-174

Lutz RV, Marcus NH, Chanton JP (1994) Hatching and viability of copepod eggs at two stages of embryological development: anoxic/hypoxic effect. Mar Biol 119:199-204

Meador JP, Ross BD, Dinnel PA, Picquelle SJ (1990) An analysis of the relationship between a sand-dollar embryo elutriate assay and sediment contaminants from stations in an urban embayment of Puget Sound, Washington. Mar Environ Res 30:251-272

Oyarzún C, Carrasco FD, Gallardo VA (1987) Some characteristics of macrobenthic fauna from the organic-enriched sediments at Talcahuano, Chile. Cah Biol Mar 28:429-446

Pradenas $E_{1}$ Rudolph A (1989) Comparación del impacto ambiental en la Bahía de Concepción producido por los residuos de las plantas de harina, aceite y congelado. Bı.ol Pesq 18:115-122 
Pridmore RD, Thrush SF, Wilcock RJ, Smith TJ, Hewitt JE, Cummings VJ (1991) Effect of the organochlorine pesticide technical chlordane on the population structure of suspension and deposit feeding bivalves. Mar Ecol Prog Ser 76:261-271

Richardson BJ, Martin M (1994) Marine and estuarine toxicity testing: a way to go? Additional siting from northern and southern hemisphere perspectives. Mar Pollut Bull 28 $138-142$

Riley \& Chester (1971) Introductıon to marine chemistry. Academic Press, London

Rosenberg R (1985) Eutrophication. The future marine coastal nuisance? Mar Pollut Bull 16:227-231

Rosenberg R (1990) Negative oxygen trends in Swedish coastal bottom waters. Mar Pollut Bull 21:335-339

Rosenberg R, Hellman B, Johansson B (1991) Hypoxic tolerance of marine benthic fauna. Mar Ecol Prog Ser 79:127-131

Rudolph A, Ahumada R. Hernández S (1984) Distribución de la materia orgánica, carbono orgánico y fósforo total en los sedimentos recientes de la Bahía de Concepción. Chile. Biol Pesq 13:71-82

Sandberg E (1994) Does short-term oxygen depletion affect predator-prey relationships in zoobenthos? Experiments with the isopod Saduria entomon. Mar Ecol Prog Ser 103: $73-80$

Stickle WB, Diehl WJ (1987) Effects of salinity on echinoderms. In: Jangoux M, Lawrence JM (eds) Echinoderm studies 2. AA Balkema, Rotterdam, p 235-285

Swartz RC, Schults DW, Distworth GR, DeBen WA (1984) Toxicity of sewage sludge to Rhepoxynius abronius, a marine benthic amphipod. Arch Environ Contam Toxicol 13: $207-216$

Taylor P (1993) The state of the marine environment: a critique of the work and role of the Joint Group of Experts on Scientific Aspects of Marine Pollution (GESAMP). Mar Pollut Bull 26:120-127

UNEP/IAEA (1982) Determination of DDTs, PCBs, PCCs and other hydrocarbons in sea-water by gas chromatography.

This article was submitted to the editor
Reference methods for marine pollution studies No 16 UNEP

UNEP/IOC/IAEA (1986) Determination of DDTs and PCBs by capillary gas chromatography and electron capture detection. Reference methods for marine pollution studies No 40. UNEP

US EPA (1976) Quality criteria for water USA Environmental Protection Agency, Washington, DC

US EPA (1982) A compilation of water quality standards for marine waters. United States Environmental Protection Agency. Office of Water Regulations and Standards, Washington DC

Van den Thillart G, Dalla Via J, Vitali G, Cortesi P (1994) Influence of long-term hypoxia exposure on the energy metabolism of Solea solea. I. Critical $\mathrm{O}_{2}$ levels for aerobic and anaerobic metabolism. Mar Ecol Prog Ser 104 $109-117$

Weber Cl, Horning WB, Klemm DJ, Neiheisel TW, Lewis PA Robinson EL, Menkedick J, Kessler F (1989) Short-term methods for estimating the chronic toxicity of effluents and receiving waters to marine and estuarine organisms. US Environmental Protection Agency, EPA/600/4-87/028, Cincinnati

Weiss RF (1970) The solubility of nitrogen, oxygen and argon in water and seawater. Deep Sea Res Oceanogr Abstr 17 . $721-735$

WHO (1989) Aldrin and dieldrin. Environmental health crite ria 91 World Health Organization, Geneva

Wilkinson L (1990) SYSTAT: the system for statistics. Systat, Inc, Evanston, IL

Zmarzly DL, Stebbins TD, Pasko D, Duggan RM, Barwick KL (1994) Spatial patterns and temporal succession in softbottom macroinvertebrate assemblages sorrounding an ocean outfall on the southern San Diego shelf: relation to anthropogenic and natural events. Mar Biol 118:293-307

Zúniga M, Roa R, Larrain A (1995) Sperm cell bioassay with the sea urchin Arbacia spatuligera on samples from polluted Chilean coastal sites. Mar Pollut Bull 30:313-319

Manuscript first received: March 3, 1995

Revised version accepted: October 17, 1995 